Marta Ples-BęBen

ORCID 0000-0003-4281-9957

Uniwersytet Śląski

w Katowicach

\title{
KRYTYKA I ROZUMIENIE W DORADZTWIE FILOZOFICZNYM
}

\begin{abstract}
AвSTRACt. Ples-Bęben Marta, Krytyka i rozumienie w doradztwie filozoficznym [Criticism and Comprehension in Philosophical Counseling]. Studia Edukacyjne nr 57, 2020, Poznań 2020, pp. 241-255. Adam Mickiewicz University Press. ISSN 1233-6688. DOI: 10.14746/se.2020.57.17

The aim of the article is to analyze "criticism" and "understanding" in their relation to philosophical counseling. The article begins by the thesis on the need to define this type of counseling as an equivalent relationship between a counselor and a client. This claim is based mainly on the Socratic sense of the essence of philosophizing as a common pursuit of wisdom and cognition. Next, criticism and understanding which seem to be abstract concepts that belong to specific doctrines are considered as useful tools in the process of creating a philosophical attitude. In this sense, they acquire their existential aspect and prove useful in the practical application of philosophy.
\end{abstract}

Key words: philosophical counseling, comprehension, critic

\section{Doradztwo filozoficzne, czyli ku wspólnemu filozofowaniu}

Doradztwo filozoficzne to stosunkowo młoda, choć zyskująca coraz szersze zainteresowanie gałąź poradnictwa. Dodajmy, że zainteresowanie to, także w Polsce, niezwykle dynamicznie się zwiększa. Oto, jak w 2000 roku Joanna Szulińska pisała na łamach „Przeglądu Filozoficznego”: „Doradztwo filozoficzne traktowane jest $\mathrm{w}$ naszym kraju wyłącznie jako pewien pomysł - często uznawany za kontrowersyjny albo wręcz nie nadający się do sensownego zrealizowania"1. Tymczasem, w niespełna dwie dekady po pu-

${ }^{1}$ J. Szulińska, Eckharta Rushmanna "Doradztwo filozoficzne”, Przegląd Filozoficzny - Nowa Seria, 2000, 3(35), s. 219. 
blikacji tych słów doradztwo filozoficzne zyskało w naszym kraju sporą popularność, o czym zaświadcza zarówno jego umocowanie instytucjonalne², jak i coraz większa liczba specjalistycznych opracowań3 ${ }^{3}$.

Nazwa "doradztwo filozoficzne", choć ustalona i powszechnie stosowana, budzi uzasadnione kontrowersje i może wprowadzać w błąd. Istotą tego rodzaju działalności nie jest bowiem doradzanie, lecz dialog, rozmowa, w której „Filozof-doradca, do którego człowiek zdecyduje się zwrócić ze swoimi problemami, podaje pomocną dłoń człowiekowi jako partnerowi, nie zaś pacjentowi czy klientowi [podkreśl. - M.P.-B.]"4. W zacytowanym zdaniu Emil Višňovský podkreśla konieczną równoważność relacji filozofujących osób, wspólnie zmierzających ku wewnętrznej przemianie w prawdzie i mądrości. Choć bowiem jedna z tych osób zwraca się do drugiej po pomoc w rozwiązaniu problemu - życiowego lub filozoficznego - i choć jedna z tych osób ma mniejszą filozoficzną wiedzę, niż druga, to podstawowym założeniem relacji doradczo-filozoficznej powinno być antydogmatyczne przekonanie o tym, że filozofia w każdym przypadku jest nieustannym dążeniem do prawdy, niekończącym się wysiłkiem poznawczym. W konsekwencji, każdy filozofujący, zarówno ten, który występuje w roli „doradcy”, jak i ten, który „zwraca się po radę”, powinien być postrzegany jako „nie-mądry”, czyli ten, który mądrości poszukuje, nigdy nie będąc w jej posiadaniu. Wszelki wysiłek mający na celu zbliżenie się do prawdy - a taki wysiłek musi charakteryzować efektywną rozmowę doradczo-filozoficzną - zakłada rozwój (czyli zbliżenie się do prawdy i mądrości) wszystkich tych, którzy ten wysiłek podjęli.

Termin „doradztwo filozoficzne” zdaje się negować równoważność dwóch (bądź dwojga) filozofujących, sugerując asymetryczną relację eksperta i laika. Ze względu na nieadekwatność tego terminu (stanowiącego bezpośredni przekład angielskiego zwrotu philosophical counseling) względem założeń filozoficznej praktyki poradniczej, w polskiej literaturze przedmiotu spotyka się różne propozycje nazw mających celniej odnosić się do swego

${ }^{2}$ Doradztwo filozoficzne można obecnie studiować m.in. na uniwersytetach w Katowicach, Opolu i Zielonej Górze. Funkcjonują także stowarzyszenia zrzeszające praktyków i sympatyków doradztwa filozoficznego: Polskie Towarzystwo Doradztwa Filozoficznego, por. https://doradztwofilozoficzneptdf.wordpress.com/ [dostęp: 30.03.2019] oraz Stowarzyszenie Doradztwa Filozoficznego „Pogadalnia”, por. http://pogadalnia.pl/ [dostęp: 30.03.2019].

${ }^{3}$ Por. L. Ostasz, Psychoterapia filozoficzna. O usprawnianiu rozumu i leczeniu psychiki, Krynica Morska 2007 (wyd. II poszerzone Warszawa 2011); Filozofia jako sztuka życia. Teorie, modele i wzorce dla doradztwa filozoficznego, red. A. Woszczyk, D. Olesiński, Katowice 2013; Studia Philosophiae Christianae, 2018, 3 (numer specjalny poświęcony problematyce doradztwa filozoficznego). Można w tym miejscu przywołać także liczne opublikowane w Polsce artykuły i rozdziały dotyczące zagadnień doradczo-filozoficznych. Niektóre z nich pojawiają się w zestawieniu bibliograficznym wieńczącym niniejszy tekst.

${ }^{4}$ E. Višňovský, Doradztwo filozoficzne jako forma praktyki filozoficznej, przekł. M. Aleksandrowicz, Colloquia Communia, 2001, 71, s. 160. 
desygnatu. Lech Ostasz wprowadza do swych rozważań określenie „mentaloterapia”, które stosuje zamiennie z terminem „psychoterapia filozoficzna”, akcentując terapeutyczną, uzdrawiającą funkcję filozofii oraz to, że celem tej szczególnej terapii jest oddziaływanie na sferę umysłu ${ }^{5}$. Tym samym tropem podąża proponując inne nazwy: „fronoterapia” (gr. fronesis - umysł), „nooterapia" (gr. nous - umysł i świadomość)", racjoterapia (łac. ratio - rozum) i „logoterapia” (gr. logos - myśl, słowo, logikon - umysł, przy czym ostatnią nazwę, na co zresztą zwraca uwagę także Ostasz, zaadaptował już do swej metody terapeutycznej Victor E. Frankl ${ }^{6}$. Przywołane próby są interesujące, choć niosą ze sobą kolejne trudności. Ze względu na nie, a także z uwagi na rozpoznawalność, a więc i czytelność nazwy "doradztwo filozoficzne”, to ona będzie służyła w dalszej części tekstu na oznaczenie omawianej w nim filozoficznej praktyki poradniczej.

Jednym z najczęściej przywoływanych kontekstów historycznofilozoficznych jest $\mathrm{w}$ doradztwie filozoficznym dialog sokratejski, a zwłaszcza metoda majeutyczna. Zgodnie z jej założeniami, filozof pełni rolę akuszera pomagającego przyjść na świat ważnym i wartościowym myślom ${ }^{7}$ Słynne stwierdzenie Sokratesa, zgodnie z którym on sam nie może nikogo nauczać, bo nie posiadł żadnej wiedzy, którą mógłby przekazać ${ }^{8}$, trafnie wskazuje na założenia współczesnego doradztwa filozoficznego. Chodzi w nim bowiem, jak podkreślał Gerd B. Aschenbach - który w Niemczech w 1981 roku otworzył pierwszą doradczą praktykę filozoficzną pod nazwą Philosophishe Praxis - o wspólne filozofowanie, a w żadnym razie nie o myślenie za innychํ. Roz-

${ }^{5}$ Por. L. Ostasz, Psychoterapia filozoficzna, s. 9. Tomasz Femiak, odnosząc się do tych propozycji, zwraca uwagę na zbyt daleko idące skojarzenia, które mogą rodzić nazwy zaproponowane przez Ostasza: „Stosowanie nazwy »mentaloterapia« oddaje wprawdzie istotę praktyki filozoficznej, ale nie odzwierciedla jej odrębności od podejścia psychologicznego. Dodatkowo człon »terapia « może budzić wyobrażenie u osób nie mających wcześniej do czynienia z doradztwem filozoficznym, że jest to kolejna forma psychoterapii. Tymczasem doradztwo filozoficzne może być traktowane tylko jako przygotowanie lub element psychoterapii $\mathrm{w}$ tradycyjnym rozumieniu". T. Femiak, Terapia filozoficzna, czyli doradztwo filozoficzne w działaniu, [w:] Psychoterapia pogranicza. Podręcznik akademicki, red. L. Grzesiuk, H. Suszek, Warszawa 2012, s. 486.

${ }^{6}$ Por. L. Ostasz, Psychoterapia filozoficzna, s. 9.

7 Oto, co na ten temat mówi Platoński Sokrates: „Więc moja sztuka położnicza zresztą tym samym się odznacza, co i sztuka tamtych kobiet, a różni się tym, że mężczyznom, a nie kobietom rodzić pomaga, i tym, że ich dusz rodzących dogląda, a nie ich ciał. A największa wartość w naszej sztuce tkwi ta, że ona na wszelki sposób wybadać potrafi, czy umysł młodzieńca widziadło tylko i fałsz na świat wydaje, czy też myśl płodną i prawdziwą. Bo ja jestem całkiem jak te akuszerki: rodzić nie umiem mądrości i o co niejeden już mnie beształ, że innych pytam, a sam nic nie odpowiadam $w$ żadnej sprawie, bo nic nie mam mądrego do powiedzenia, to słusznie mnie besztają". Platon, Teajtet, przekł. W. Witwicki, Warszawa 1959, s. 28-29.

${ }^{8}$ Por. Platon, Obrona Sokratesa, [w:] Platon, Eutyfron, Obrona Sokratesa, Krition, przekł. W. Witwicki, Warszawa 1958, s. 96-100.

${ }_{9}$ Por. J. Szulińska: Eckharta Rushmanna „Doradztwo filozoficzne”, s. 220. 
mowa doradczo-filozoficzna ma więc być współfilozofowaniem, wspólnym pokonywaniem drogi ku samopoznaniu, wspólnie podejmowaną pracą na rzecz troski o duszę.

Innym kontekstem, który warto tu przywołać, jest filozofia dialogu i kluczowa dla niej kategoria spotkania. W jej obszarze rozróżnia się dwa rodzaje relacji, w których poznajemy drugiego człowieka. Jak pisze na ten temat Małgorzata Opoczyńska,

Relacja ta może przyjąć generalnie dwa kształty: może być, po pierwsze, relacją tzw. "pochyłą”, w której poznający stawia się „powyżej” poznawanego i niejako „z góry”, "od zewnątrz" na niego patrzy, lub, po drugie, może być relacją „poziomą", w której poznający i poznawany znajdują się na jednej płaszczyźnie, są sobie - jako dwa podmioty - równi i wspólnie, w sposób aktywny uczestniczą w procesie poznawania ${ }^{10}$.

Pierwszą z wymienionych tu relacji można za Maxem Schelerem i Victorem E. Franklem nazwać mianem uprzedmiotawiającej, natomiast nawiązując do Martina Bubera można nazwać ją relacją Ja-Ono. W drugim typie relacji zachowana zostaje natomiast podmiotowość obydwu stron i tylko ona zasługuje na miano spotkania otwierającego drogę ku poznaniu Drugiego jako osoby. Buber nazywa taki typ relacji - opartej na podmiotowości, równoprawności i równoważności tych, którzy ją konstytuują - relacją Ja-Ty. Tylko ona daje możliwość wspólnego filozofowania i tylko w niej może urzeczywistnić się wspólnota zaangażowania w dążenie ku poznaniu i prawdzie ${ }^{11}$.

Sokratejski dialog i kategoria spotkania pozwalają nakreślić podstawowe założenia doradztwa filozoficznego. Nie znaczy to jednak, że są to jedyne konteksty, do których odwołują się praktycy tego rodzaju doradztwa. Najczęściej przywoływaną spośród koncepcji filozoficznych wydaje się - poza sokratejską - tradycja stoicka ${ }^{12}$, a także pozostałe nurty filozofii hellenistycznej. Ze współczesnych teorii przede wszystkim zwraca się uwagę na koncepcje

${ }^{10}$ M. Opoczyńska, Psychologia egzystencjalna wobec pytań o możliwości i granice poznania drugiego człowieka, [w:] Wprowadzenie do psychologii egzystencjalnej, red. M. Opoczyńska, Kraków 1999, s. 169.

${ }^{11}$ Trzeba podkreślić, że zdaniem Bubera relacja personalna nie może urzeczywistnić się w terapii, jako że nie ma w niej mowy o wzajemności, stanowiącej dlań - obok otwartości i zaufania - warunek konieczny tego typu relacji. Jeśli jednak przyjmiemy model rozmowy doradczej jako współfilozofowania, to będzie można mówić także o wzajemności. Szerzej na temat Buberowskiej koncepcji dialogu i jej odniesienia do terapii: por. Z. Rosińska, Psychoterapia i filozofia, [w:] Psychoterapia pogranicza. Podręcznik akademicki, red. L. Grzesiuk, H. Suszek, Warszawa 2012, s. 152-153.

12 Por. m.in. Znak, 2019, 1(764), s. 6-39 (znacząca część numeru została święcona stoicyzmowi jako sztuce życia i jego współczesnym odczytaniom i zastosowaniom); M. Fabjański, Stoicyzm uliczny. Jak oswajać trudne sytuacje, Warszawa 2010; T. Mazur, O stawaniu się stoikiem. Czy jesteście gotowi na sukces? Warszawa 2014; T. Mazur, Fiasko. Podręcznik nieudanej egzystencji, Warszawa 2012; P. Stankiewicz, Sztuka życia wedtug stoików, Warszawa 2014; P.J. Vernezze, Don't worry, Be Stoic. Antyczna mądrość na trudne czasy, przekł. A. Aduszkiewicz, Warszawa 2013. 
powstałe $\mathrm{w}$ ramach szeroko rozumianego nurtu filozofii egzystencji, która pozostaje także istotną inspiracją dla innych typów poradnictwa ${ }^{13}$.

Celem niniejszego artykułu jest poszerzenie ram wytyczonych przez wspomniane wyżej odniesienia i rozważenie dwóch kategorii: „krytyka” i „rozumienie”, jako narzędzi szczególnie użytecznych w doradczej praktyce filozoficznej. Obydwie kategorie można rozważać w ramach konkretnych kontekstów historycznofilozoficznych, a także można je ujmować jako elementy postawy filozoficznej, czy też radykalnie: jako warunki możliwości filozofowania w ogóle. W dalszej części artykułu kategorie te zostaną odniesione do nurtów i teorii, w ramach których zostały wypracowane, lecz ta analiza historycznofilozoficzna będzie podporządkowana problemowemu ujęciu ich jako składowych metody filozoficznej jako takiej.

\section{Ku otwartości myślenia. O krytyce filozoficznej}

W perspektywie dziejów filozofii, pojęcia krytyki i krytycyzmu najczęściej wywołują skojarzenie z tak zwanym „krytycznym” okresem twórczości Immanuela Kanta, zainaugurowanym w 1781 roku publikacją pierwszego wydania Krytyki czystego rozumu. Przyjrzyjmy się Kantowskiemu ujęciu tych pojęć, skądinąd podejmowanemu i reinterpretowanemu do dzisiaj.

Grecki źródłosłów słowa „krytyka” to krínein, które dosłownie oznacza rozróżniać, rozstrzygać ${ }^{14}$. Etymologia sygnalizuje więc, że krytyka filozoficzna może mieć zarówno sens negatywny, jak i pozytywny. Precyzując cele i metodę swej filozofii krytycznej, Kant akcentuje znaczenie obydwu tych dróg, odnosząc się między innymi do zastanych sporów metafizycznych. W Przedmowie do pierwszego wydania Krytyki czystego rozumu pisze o metafizyce jako polu bitwy niekończących się sporów, możliwości uzdrowienia tego stanu rzeczy upatrując w krytycznym badaniu źródła teorii metafizycznych, którym jest spekulatywny (czysty) rozum. Zdaniem Kanta, jedynie analiza

${ }^{13}$ Por. m.in. Człowiek, wartości, sens. Studia z psychologii egzystencji: logoteoria i nooteoria, logoterapia i nooterapia, red. K. Popielski, Lublin 1996; Wprowadzenie do psychologii egzystencjalnej, red. M. Opoczyńska, Kraków 1999; K. Popielski, P. Mamcarz, Trauma egzystencjalna a wartości, Warszawa 2015; M. Opoczyńska, Genealogie psychoterapii: fragmenty dyskursu egzystencjalnego, Kraków 2016; A. Längle, Gdy rodzi się pytanie o sens: praktyczne zastosowanie logoterapii, przekł. A. Grzegorczyk, A. Szymczak, Warszawa 2016. Warto w tym miejscu podkreślić także, że filozofia egzystencji w jej różnych sformułowaniach zainspirowała licznych wybitnych psychoterapeutów, m.in. Victora E. Frankla, Rollo Maya i Irvina D. Yaloma, na co niezwykle często sami wskazują. Por. np. V.E. Frankl, Lekarz i dusza: wprowadzenie do logoterapii i analizy egzystencjalnej, przekł. R. Skrzypczak, Warszawa 2017; R. May, O istocie człowieka. Szkice z psychologii egzystencjalnej, przekł. M. Moryń, Z. Wiese, Poznań 1995; I.D. Yalom, Psychoterapia egzystencjalna, przekł. A. Tanalska-Dulęba, Warszawa 2008.

${ }^{14}$ Por. J. Herbut, Krytycyzm, [w:] Powszechna encyklopedia filozofii, t. 6, red. A. Maryniarczyk, M.A. Krąpiec i in., Lublin 2005, s. 92. 
i ocena granic możliwości rozumu umożliwia udzielenie prawomocnej odpowiedzi na pytanie o możliwość bądź niemożliwość metafizyki. W ten sposób negacja zastanej sytuacji metafizyki prowadzi ku pozytywnym rezultatom poznawczym (co nie musi być równoznaczne z twierdzącą odpowiedzią na zadane pytanie, w tym przypadku o możliwość metafizyki jako nauki) ${ }^{15}$.

Bez postulowanej przez Kanta krytyki „rozum znajduje się niejako w stanie natury"16, jest nie-krytyczny, a więc dogmatyczny. Natomiast krytyka to - zgodnie z kolejnym barwnym Kantowskim porównaniem - stawianie rozumu przed trybunałem, przed sądem, w którym jasna argumentacja i wnioskowanie umożliwią dotarcie do prawdy, na ile jest ona osiągalna ${ }^{17}$. Krzysztof Michalski, we wnikliwej analizie Kantowskiej Przedmowy do pierwszego wydania Krytyki czystego rozumu, celnie przeciwstawia dogmatyzm - a więc stan wojny i toczące się w jej mroku metafizyczne bitwy - krytycyzmowi i związanej z nim jasności postępującego według ściśle określonych zasad sądowego procesu ${ }^{18}$. Przedsięwzięcie krytycznego namysłu jest więc różnoznaczne z przejściem od chaosu ku opracowanej zgodnie z jasnymi zasadami metodzie.

Kantowski krytycyzm ma umożliwić ocenę granic i możliwości rozumu i jako taki wymaga od filozofującego abstrahowania od sądów metafizycznych, których prawomocność ma być przedmiotem badania. Tym samym zakłada szczególną postawę, którą cechuje między innymi umiejętność hierarchizowania tego, co dane oraz analitycznego odniesienia się do tak wyszczególnionych elementów. W tym rozszerzonym - choć wychodzącym od Kanta - sensie, być krytycznym to znaczy być wnikliwym, zmierzać ku temu, co podstawowe, pytać o ostateczne ufundowanie tego, co dane.

Tak więc, krytykę filozoficzną można rozumieć w ścisłym sensie jako filozoficzną metodę (niekoniecznie Kantowską) lub w sensie szerszym: jako po-

15 Por. I. Kant, Krytyka czystego rozumu, t. 1, przekł. R. Ingarden, Warszawa 1986, s. 7-20.

16 Tamże, s. 492.

$17,(.$.$) jest (...) wezwaniem skierowanym do rozumu, żeby się na nowo podjął najuciąż-$ liwszego z wszelkich swych zadań, a mianowicie poznania samego siebie, i żeby ustanowił trybunał, który by go umocnił w jego sprawiedliwych wymaganiach, a natomiast mógł odrzucić wszelkie bezpodstawne uproszczenia i to nie za pomocą dowolnych rozstrzygnięć, lecz na podstawie wiecznych i niezmiennych praw, a trybunałem takim jest tylko sama krytyka czystego rozumu". I. Kant, Krytyka czystego rozumu, s. 10-11.

18 ,"Krytyka« wydobywa bowiem na jaw granice czystego rozumu, wyznacza jego możliwości - a więc pozwala ustalić, kiedy użycie czystego rozumu jest prawomocne, kiedy zaś nie. Krytyka czystego rozumu umożliwia więc rozumowi wyjście ze stanu »wojny«; pozwala przekształcić »wojnę« w »proces sądowy«. Wojna, bitwa - to symboliczny obraz »przedkrytycznego« stanu rozumu, proces sądowy - rozumu krytycznego. Warunkiem przemiany »wojny« w »proces « jest ustanowienie »trybunału « - krytyki czystego rozumu". K. Michalski, Próba interpretacji: "Przedmowa" do pierwszego wydania "Krytyki czystego rozumu”, Teksty: teoria literatury, krytyka, interpretacja, 1976, 3(27), s. 23. 
stawę zakładającą szczególny stosunek siebie, świata i drugiego człowieka. Być krytycznym, to najogólniej znaczy: nie być dogmatycznym. Takie rozumienie krytyki jest uniwersalne i nie zawęża się do żadnego z filozoficznych nurtów. Jest związane z nieustającym, sokratejskim postulatem filozofii, by pozostawać otwartym na to co nowe, by uwzględniać inne niż swój punkty widzenia, by zmierzać ku prawdzie, zamiast zadowalać się mniemaniami. Józef Herbut, analizujący pojęcie krytycyzmu, pisze między innymi tak:

[jest to] cecha myślenia polegająca na wieloaspektowym ujmowaniu spostrzeganych faktów, konfrontowaniu ich z własnymi doświadczeniami i poglądami, poszukiwaniu ich racji oraz gotowości do korygowania swoich poglądów w sytuacji zasadnej argumentacji ${ }^{19}$.

Dostrzeganie złożoności, wielowymiarowości podejmowanego problemu, gotowość do zmiany zdania, świadomość cząstkowego charakteru swej wiedzy - oto niektóre z cech tak pojmowanej postawy krytycznej.

Podkreślając potrzebę filozofii jako wolnego aktu, Josef Peiper kładzie nacisk na otwartość jako warunek konieczny filozofowania. Rdzeniem filozofii byłoby więc ",to otwarcie się na nie zawężony przedmiot ludzkiego poznania, to znaczy na całościowo ujętą rzeczywistość, którą należy rozważać w każdym możliwym do pomyślenia aspekcie" ${ }^{\prime 20}$. Nie uwzględniając złożoności tego co jest, redukując rzeczywistość na przykład do tego co daje się zracjonalizować, skazujemy się na jej uproszczony obraz. Tym samym, zarzucamy postawę krytyczną, nakazującą całościowe i wnikliwe rozważenie badanego przedmiotu. Tymczasem, jak pisze Peiper: „Być «krytycznym» to dla kogoś filozofującego nie znaczy w pierwszym rzędzie: dopuszczać do uznawania tylko tego, co absolutnie pewne; lecz: dbać o to, by niczego nie pominąć" ${ }^{21}$.

Można zadać w tym kontekście następujące pytanie: czy tak rozumiana krytyczność jest w ogóle możliwa? Czy możliwe jest myślenie, które nie pomija niczego? ${ }^{22}$ Nawet jeśli - choć zapewne warunkowo - udzielimy tu odpowiedzi twierdzącej, to nasuwa się kolejne pytanie: co możemy zyskać dzięki krytycznemu przemyśleniu wszystkiego, czego przemyślenie leży w granicach ludzkich możliwości i jak taką procedurę przeprowadzić?

Interesującą odpowiedź znajdziemy u Nicolaia Hartmanna związanego $\mathrm{z}$ neokantyzmem, a więc filozoficznym nurtem reinterpretującym Kantowski krytycyzm. Hartmann, za Kantem uznający ograniczoność ludzkiego poznania, utożsamia kategorię „metafizyka” ze wszystkim, co pozostaje dla

${ }^{19}$ J. Herbut: Krytycyzm, s. 92.

${ }^{20}$ J. Peiper, W obronie filozofii, przekł. P. Waszczenko, Warszawa 1985, s. 36.

${ }^{21}$ Tamże, s. 37.

22 Por. A.J. Noras, Co to znaczy "być krytycznym"? [w:] Prawda a metoda, red. J. Jaskóła, A. Olejarczyk, Wrocław 2003, s. 321. 
człowieka irracjonalne. Metafizyka nie jest więc szczególną dyscypliną filozoficzną, lecz zbiorem problemów rozsianych wszędzie tam, gdzie ludzkie myślenie napotyka na opór. Metafizyki nie definiuje problematyka duszy, Boga, czy wszechświata, a sygnalizujące ją irracjonalne residuum ${ }^{23}$. Stawiając sprawę tak, Hartmann zakreśla horyzont poznawczy człowieka, wskazując jednocześnie jego granice. Dobitnie podkreśla, że „dbać o to, by niczego nie pominąć" można jedynie w ramach tego, co dane jako racjonalne i co daje się zracjonalizować.

Jako narzędzie poznawcze, Hartmann proponuje trójstopniową metodę, składającą się z: 1) fenomenologii, czyli wiernego opisu fenomenów, tego, co dane; 2) aporetyki, której celem jest wydobycie $z$ fenomenów ich aporii, czyli tego, co w nich niezrozumiałe, przy uwzględnieniu stanu badań danego problemu; 3) teoriii ${ }^{24}$. Trzeci etap Hartmannowskiej metody nie ma być jednak tworzeniem doktryny, lecz "czystym oglądaniem" - poprzedzonym przez krytyczny namysł i przez niego umożliwionym. Pisząc o teorii, Hartmann nawiązuje do etymologii tej kategorii. Pisze: „Jej sens polega tylko na wnikliwym oglądaniu, na czystym wglądzie (Einsicht) jako takim, który rozglądając się szeroko dookoła i postępując bardzo ostrożnie, więcej widzi niż naiwne spoglądanie" 25 . Można powiedzieć, że słowa te oddają istotę krytycyzmu jako postawy - troszczącej się o to, by niczego nie pominąć, wnikliwej, świadomej swych ograniczeń.

W krytykę filozoficzną - niezależnie od tego, czy będziemy go rozumieć wąsko: jako metodę sformułowaną w ramach konkretnej doktryny, czy też szeroko: jako postawę będącą nieodłącznym elementem filozofowania - wpisany jest postulat samodzielności myślenia, wyzbycia się stanowiskowości, dogłębnego wnikania w istotę badanego problemu, uwzględniania jego wieloaspektowości i złożoności, wreszcie gotowości do przeformułowania lub porzucenia dotychczas wypracowanych założeń i ustaleń, jeśli pojawiły się ku temu ważne przesłanki. Jako taka, krytyka ma znaczenie nie tylko teoriopoznawcze czy metodologiczne, lecz także egzystencjalne. Postawa filozoficznego krytycyzmu staje się zadaniem egzystencji, warunkiem stawania się i rozwoju rozumianego jako pogłębianie świadomości i wrażliwości filozofującego na złożoność świata i własnego Ja.

${ }^{23}$ „W tym sensie metafizyczne są wszystkie problemy, które wymykają się ostatecznym rozwiązaniom, obojętnie do jakiej dziedziny filozofii należą. Są też rzeczywiście rozproszone po wszystkich dziedzinach, kryją się wszędzie za tym, co poznawalne. A wszelką dalszą pracę nad tymi pytaniami można uznać za pracę metafizyczną, jakąkolwiek pójdzie drogą". N. Hartmann, Systematyczna autoprezentacja, [w:] N. Hartmann, Myśl filozoficzna i jej historia. Systematyczna autoprezentacja, przekł. J. Garewicz, Toruń 1994, s. 84-85.

${ }^{24}$ Por. tamże, s. 82-83.

${ }^{25}$ Tamże, s. 83. 
Czy taka postawa może pomóc w stawianiu czoła wyzwaniom codzienności? Innymi słowy: czy może być użyteczna poza akademią, w której filozofię uprawia się niejako „zawodowo"? Jestem przekonana, że tak. Przede wszystkim dlatego, że postawa krytyczna wiąże się z umiejętnością dogłębnej analizy problemów przy jednoczesnej świadomości, że istnieją problemy, których nie da się rozwiązać, a także takie, które mogą mieć kilka równoważnych rozstrzygnięć. Krytyka filozoficzna rozumiana jako metoda myślenia wykształca precyzję, otwartość, zdolność dostrzeżenia innego, niż tylko własny punkt widzenia. Patrząc krytycznie na świat i samych siebie, dostrzegamy wieloaspektowość problemów, z którymi musimy się mierzyć, związków międzyludzkich, w które wchodzimy, sytuacji, w których się znajdujemy, zależności, w które jesteśmy uwikłani. Nabywamy także świadomości istnienia tego, co irracjonalne, co wymyka się porządkowi ratio. Nieodłącznie związany z krytyką sceptycyzm ujawnia także fakt istnienia ludzkich ograniczeń - zarówno jeśli chodzi o poznanie, jak i działanie. Nie wszystko, czego dowiadujemy się dzięki krytyce filozoficznej jest krzepiące, jednak nie o pokrzepienie tu chodzi, a o możliwie najpełniejsze uchwycenie samego siebie, swego życia, otaczającego świata.

Czy bycia krytycznym da się nauczyć? Odpowiedź musi tu być twierdząca, choć trzeba zaznaczyć, że nie istnieje żaden prosty schemat, czy „droga na skróty", która umożliwiłaby osiągnięcie postawy filozoficznego krytycyzmu. Lech Ostasz proponuje wprawdzie kilka użytecznych narzędzi doradczo-filozoficznych, które bez wątpienia pomagają tę postawę krytyczną ukształtować (przede wszystkim chodzi tu o definiowanie pojęć, rezygnację z wielkich kwantyfikatorów, czy o analizę założeń sądów głoszonych przez siebie i innych) ${ }^{26}$. Wykorzystywanie metod wypunktowanych przez Ostasza jest jednak tożsame z filozofowaniem. Wydaje się więc, że postawa krytyczna pojawia się wraz z zamiłowaniem do filozofowania, a następnie rozwija się dzięki stopniowemu studiowaniu teorii, metod i narzędzi filozoficznych. Jako taka jest drogą, zmierzaniem ku mądrości, nigdy nie zakończoną pracą nad sobą i własnym rozumieniem świata. Porzucenie tej drogi, uznanie, że "już wystarczy”, ponieważ osiągnęliśmy zadowalający poziom krytycyzmu, byłoby zaprzeczeniem filozoficznej krytyki i wkroczeniem na ścieżkę dogmatyzmu.

\section{O rozumieniu, czyli nauka milczenia}

Termin „rozumienie”, podobnie jak pojęcie krytycyzmu, w swym znaczeniu historycznofilozoficznym wpisuje się w ściśle określoną metodę przypisaną do konkretnej teorii. W tym wypadku - hermeneutyki. Niezależnie od

\footnotetext{
${ }^{26}$ Por. L. Ostasz, Psychoterapia filozoficzna, s. 100-109 i 115-123.
} 
tych powiązań, będę chciała wykazać, że choć w perspektywie historycznej rozumienie jest kategorią metodologiczną, to w odniesieniu do tego terminu można także mówić o pewnej szczególnej postawie filozoficznej, wynikającej z przemyślenia i uznania tejże kategorii. Analizując tę postawę, wykroczę poza teksty powstałe w kręgu filozofii hermeneutycznej. Podobnie jak krytycyzm, tak i rozumienie - jako postawa skierowana ku światu i ku własnemu życiu - stanowi w moim przekonaniu składową filozofowania w ogóle, nie musi być zatem ograniczane do żadnego myślowego nurtu, nawet jeśli z niego się wywodzi.

Punktem wyjścia niech będą słowa Wilhelma Diltheya, który na przełomie XIX i XX wieku wprowadził do filozofii hermeneutykę jako metodę. W swym artykule z 1911 roku, Dilthey pisze następująco: „Filozofia winna nie w świecie, lecz w człowieku poszukiwać wewnętrznej struktury swych przekonań. Dążeniem człowieka dzisiejszego jest zrozumieć życie przeżywane przez człowieka" ${ }^{27}$. Zastanówmy się nad tymi słowami, co to znaczy: zrozumieć życie, które przeżywamy?

Dilthey przeciwstawia filozoficzne rozumienie zmierzającemu ku abstrakcji poznaniu naukowemu. Pisze następująco:

Nauka analizuje, a zatem rozwija na podstawie wyizolowanych jednorodnych stanów rzeczy ich ogólne relacje; religia, poezja i autentyczna metafizyka wyrażają znaczenie i sens całości. Tamta poznaje, te rozumieją ${ }^{28}$.

Nauka w swym dążeniu do abstrahowania oraz uogólniania tego co konkretne i dane $\mathrm{w}$ jednostkowym doświadczeniu, ze swej istoty pomija i redukuje życie do tych jego aspektów, które można uogólnić. Tymczasem, w życiu każdego człowieka pojawiają się nie dające się uśrednić stany, nastroje i przebłyski zaświadczające o niedyskursywności, a więc także o niemożności zobiektywizowania pełni ludzkiego doświadczenia. Ta niemożność wynika z istotowej antynomiczności życia, odsłaniającej jego metafizyczny, irracjonalny charakter:

Ze zmiennych doświadczeń życiowych wyłania się wobec nastawionego na całość ujęcia pełne sprzeczności oblicze życia; jego charakter życiowy i zarazem odpowiadający prawu, rozum i samowola, prezentując coraz to nowe strony, w szczegółach może przejrzyste, lecz w całości doskonale zagadkowe ${ }^{29}$.

Przedstawianie życia jako w pełni dającego się poznać i zracjonalizować jest zapoznaniem jego złożoności i ucieczką od tego, co wymyka się poznaniu.

${ }^{27}$ W. Dilthey, Typy światopoglądów i ich rozwinięcie w systemach metafizycznych, [w:] W. Dilthey, O istocie filozofii i inne pisma, przekł. E. Paczkowska-Łagowska, Warszawa 1987, s. 119.

${ }^{28}$ Tamże, s. 125.

${ }^{29}$ Tamże, s. 123. 
Tym, czego nie daje się uśrednić, są momenty, które z jednej strony można uznać za uniwersalne, jako wpisane w los każdej jednostki. $Z$ drugiej strony, dla każdego przeżywającego je człowieka stanowią wyzwanie. Fakt ich powszechności nie łagodzi bowiem ani samotności, w której wobec nich stajemy, ani tego, że nie da się ich do końca zgłębić. Dilthey nazywa je zagadką życia i pisze na ten temat następująco:

Powiązania życiowe i oparte na nich doświadczenia dusza stara się ująć w całość i nie jest w stanie tego dokonać. Ośrodek tego wszystkiego, co niepojęte, stanowią: poczęcie, narodziny, rozwój i śmierć. Istota żywa wie o śmierci, a jednak nie potrafi jej pojąća

Odnieśmy się do ostatniej ze wspomnianych kwestii: cóż z tego, że potrafimy uchwycić i nazwać kolejne fizjologiczne procesy zachodzące w ciele umierającego człowieka? Kategoryzujący, racjonalizujący opis nie da nam - i dać nie może - odpowiedzi na pytanie: jaki to ma sens? Na czym polega sens śmierci? Śmiertelności? Życia jako skończoności?

Nauka nie jest $\mathrm{w}$ stanie odpowiedzieć na te pytania, ponieważ dotyczą one kwestii, które wymykają się racjonalności. Dlatego Dilthey uznaje, że ich właściwymi adresatami są filozofia, poezja i religia, które kierują się ku temu co jednostkowe. Chcą uchwycić konkret w jego integralności na tyle, na ile to możliwe. Dążą do tego, aby uchwycić sens, zamiast wpisać go w formułę, która pasując do każdego przypadku, jednocześnie wydaje się żadnego nie dotyczyć. Na tym polega istota rozumienia w Diltheyowskim ujęciu: nauka wyjaśnia, a więc opisuje, racjonalizuje i uśrednia, filozofia, poezja i religia rozumieją, czyli kierują ku sensowi.

W uwagi te niezwykle trafnie wpisuje się wymierzone w ideę Heglowskiego panracjonalizmu stwierdzenie Sørena Kierkegaarda, zgodnie z którym to co wewnętrzne przewyższa to co zewnętrzne, zaś „liczba nieparzysta jest doskonalsza od parzystej" ${ }^{\prime 1}$. Nie wszystko bowiem daje się zmediatyzować, nie wszystko można uogólnić, a jednostki wraz z jej subiektywnością nigdy nie uda się sprowadzić do tego, co powszechne. Wyraźnie pokaże to dwudziestowieczna filozofia egzystencji kontynuująca myśl Duńczyka. Przytoczmy słowa Jeana Wahla, który na temat przedmiotu i istoty egzystencjalizmu pisze tak: „Chodzi bowiem o kwestie, które nie mogą być raczej tematami rozmowy, powinno się je rozważać podczas samotnej medytacji”32.

Komentując słowa Wahla, można wskazać, że kategoria rozumienia akcentuje niedyskursywność życia, nie dającą się zobiektywizować wyjątkowość ludzkiego losu. Skłania więc do pytania o możliwości rozumu i tworzonej

30 Tamże, s. 123-124.

31 S. Kierkegaard, Bojaźń i drżenie, [w:] S. Kierkegaard, Bojaźń i drżenie. Choroba na śmierć, przekł. J. Iwaszkiewicz, Warszawa 1982, s. 73.

32 J. Wahl, Krótka historia egzystencjalizmu, przekł. J.A. Prokopski, Wrocław 2004, s. 16. 
przezeń nauki. Każe zastanowić się nad znaczeniem tego, co z konieczności musi zostać pominięte $\mathrm{w}$ naukowej analizie. Co jesteśmy $\mathrm{w}$ stanie pomyśleć lub powiedzieć na temat tego, co dane w bezpośrednim, jednostkowym doświadczeniu tego, co stanowi nieusuwalny element egzystencjalnego ludzkiego bytowania? Być może jedyną odpowiedzią może być milczenie, któremu towarzyszy wnikliwy wgląd?

W tym miejscu spotykają się postawa krytyczna i rozumienie. Krytyczny ogląd (theoria) oparty na rozważeniu wszystkiego, co można rozważyć (a więc dbający o to, by niczego nie pominąć) dociera do tego, co nie daje się zracjonalizować, co więc - zgodnie ze słowami Nicolaia Hartmanna - jest problemowe, czyli metafizyczne. Do sensu, do tajemnicy, o których nie możemy mówić, jako że wykraczają poza język pojęć naukowych, które uchwycić mogą jedynie sztuka, religia i niekiedy filozofia. Cytowany już Josef Pieper stwierdza:

Theoria jako egzystencjalny akt człowieka zmierza (...) ku czystemu rozumiejącemu dosłyszeniu rzeczywistości, zmierza ku prawdzie i niczemu więcej (...). Dlatego filozofowanie (jako rozważanie całości rzeczywistości i możliwie najczystsze urzeczywistnienie takiej theoria), to: słuchanie tak bardzo całkowite i zupełne, że tego słuchającego milczenia nic nie zakłóca i nie przerywa - nawet pytanie ${ }^{33}$.

W kolejnym zdaniu Pieper potwierdza podział Diltheya: „Otóż to właśnie tworzy różnicę między nauką szczegółową a filozofią. Nauka nie milczy, ona pyta" ${ }^{34}$.

Nasuwa się pytanie o użyteczność rozumienia i milczenia jako egzystencjalnego aktu następującego po krytycznym, wnikliwym oglądaniu tego co dane. Pytanie to zdaje się szczególnie istotne w kontekście doradztwa filozoficznego - na co bowiem może zdać się milczenie temu, kto do doradcy przychodzi o pomoc w rozwiązaniu swych codziennych problemów?

Można tu zapewne udzielić różnych odpowiedzi, jako że milczenie może spełniać wiele funkcji i wynikać z odmiennych przyczyn. Niezwykle trafnie systematyzuje tę kwestię Gabriel Liiceanu. Oddajmy mu zatem głos:

W świecie ducha milczenie może mieć przynajmniej następujące sensy:

1) Dialog, jako forma dynamiki ducha, jest naprzemiennością mówienia i milczenia. W tych warunkach nieumiejętność milczenia oznacza unieruchomienie ducha, głupi monolog, kręcenie się w ciasnym kręgu własnego ducha. Jest to więc słowotok, logorrea.

2) W innym sensie milczenie jest zasadą samouctwa, etapem nieodzownym wszelkiej pajdei, Bildung. To ów czas „przyjmowania towaru”, duchowej regeneracji, ładowania akumulatorów itd. W każdej biografii kulturalnej muszą być momenty, gdy nie

${ }^{33}$ J. Peiper, W obronie filozofii, s. 33.

${ }^{34}$ Tamże. 
produkujesz, lecz tylko konsumujesz kulturę, podczas gdy zatem powinieneś milczeć. Odmowa milczenia oznacza tu powtarzanie w kółko tego samego, dreptanie w miejscu, obumieranie na skutek nieodnawiania własnej substancji.

3) Milczenie może być formą przyznania się do niemożności wyrażenia jakiegoś istotnego sensu lub też wyznania, że nie mamy nic istotnego do powiedzenia. Heidegger pisze: „Człowiek, nim zacznie mówić, powinien na powrót wsłuchać się w głos Bytu, nie obawiając się, że słuchając tego imperatywnego wezwania, sam niewiele, bądź rzadko będzie miał coś do powiedzenia. Tylko w ten sposób można słowu przywrócić jego bezcenną, istotną wartość, człowiekowi zaś udostępnić schronienie w wielkim pałacu prawdy bytu". W tym aspekcie odmowa milczenia oznacza pozostanie na powierzchni rzeczy, ślizganie się po niej, wprowadzanie inflacji w przestrzeń słowa.

4) Milczenie może być formą godności ducha, protestu. Zamykasz się w milczeniu, gdy wokół ciebie gada się zbyt dużo i nikczemnie. Odmowa milczenia oznacza tu więc współudział w niemoralnym spisku słowa.

5) Wreszcie „nauczenie się milczenia” można rozumieć jako korektę w postępowaniu, opartą na doświadczeniu negatywnych skutków mówienia. Tym sposobem milczenie staje się wyrazem roztropności ${ }^{35}$.

Liiceanu wykazuje, że milczenie może mieć wymiar metafizyczny, twórczy, moralny, a nawet polityczny. Można milczeć za czymś lub przeciwko czemuś. Milczenie może odzwierciedlać duchową pustkę, ale także wewnętrzny nadmiar. I wreszcie, milczenie może stać się jedynym dostępnym środkiem wyrazu, kiedy wszystkie inne zawodzą. Do tego ostatniego znaczenia, omówionego przez Liiceanu w trzecim punkcie, zmierza przedstawiony w niniejszym tekście wywód. To w tak rozumianym milczeniu zbiegają się bowiem kategorie krytycyzmu i rozumienia.

Milczenie ujęte jako jedyny możliwy środek wyrazu w obliczu irracjonalnego, uwyraźnia ograniczenia człowieka jako poznającego i działającego podmiotu. W ten sposób filozoficzna postawa ufundowana na krytyce i rozumieniu, postawa, która może do tak pojmowanego milczenia prowadzić, stanowi pogłębiony namysł nad sytuacją egzystencjalną człowieka i jego miejscem w świecie.

Nawiązując do przedstawionego $\mathrm{w}$ artykule rozumienia doradztwa filozoficznego jako wspólnego filozofowania i wspólnego zmierzania ku prawdzie oraz mądrości, chcę podkreślić wartość filozoficznej postawy jako fundamentu doradczo-filozoficznego dialogu. By tę postawę wykształcić, konieczne jest podjęcie trudu filozofowania. Trud ten jest ważniejszy od wiedzy o pojęciach, teoriach, czy metodach. Wykształcenie filozoficznej postawy z pewnością wzbogaci życie filozofującego, dostarczy mu bowiem narzędzi do wnikliwego wglądu we własne życie w pełni jego złożoności, z jego pro-

${ }^{35}$ G. Liiceanu, Dziennik z Păltinişu. Pajdeja jako model w kulturze humanistycznej, przekł. I. Kania, Sejny 2001, s. 185-186. 
blemami, relacjami, radościami i troskami. Dostarczy narzędzi do rozwoju, do samorozumienia, do stawania się sobą. Powinno więc leżeć w centrum zainteresowań zarówno każdego filozoficznego doradcy, jak i jego klienta.

Krytycyzm i rozumienie są pojęciami ściśle wpisanymi w dzieje filozofii, nie przywołuje się ich jednak w pierwszej kolejności jako przydatnych w doradczo-filozoficznej praktyce. A jednak warto akcentować ich egzystencjalny wymiar: zarówno krytyczny namysł, któremu towarzyszy świadomość ludzkich ograniczeń poznawczych, jak i rozumienie, nastawione na sens umykający naukowej analizie, umożliwiają pogłębioną refleksję nad ludzką kondycją przez wskazanie nieoczywistości tego, co w potocznym, codziennym ujęciu siebie i świata uznajemy za oczywiste.

\section{BIBLIOGRAFIA}

Człowiek, wartości, sens. Studia z psychologii egzystencji: logoteoria i nooteoria, logoterapia i nooterapia, red. K. Popielski, Katolicki Uniwersytet Lubelski, Lublin 1996.

Dilthey W., Typy światopoglądów $i$ ich rozwinięcie w systemach metafizycznych, [w:] W. Dilthey, O istocie filozofii i inne pisma, przekł. E. Paczkowska-Łagowska, Państwowe Wydawnictwo Naukowe, Warszawa 1987.

Fabjański M., Stoicyzm uliczny. Jak oswajać trudne sytuacje, Wydawnictwo Czarna Owca, Warszawa 2010.

Femiak T., Terapia filozoficzna, czyli doradztwo filozoficzne w dziataniu, [w:] Psychoterapia pogranicza. Podręcznik akademicki, red. L. Grzesiuk, H. Suszek, Eneteia - Wydawnictwo Psychologii i Kultury, Warszawa 2012.

Filozofia jako sztuka życia. Teorie, modele i wzorce dla doradztwa filozoficznego, red. A. Woszczyk, D. Olesiński, Expol, Katowice 2013.

Frankl V.E., Lekarz $i$ dusza: wprowadzenie do logoterapii i analizy egzystencjalnej, przekł. R. Skrzypczak, Wydawnictwo Czarna Owca, Warszawa 2017.

Hartmann N., Myśl filozoficzna i jej historia. Systematyczna autoprezentacja, przekł. J. Garewicz, Comer, Torun 1994.

Herbut J., Krytycyzm, [w:] Powszechna encyklopedia filozofii, t. 6, red. A. Maryniarczyk, M.A. Krąpiec i in., Polskie Towarzystwo Tomasza z Akwinu, Lublin 2005.

Kant I., Krytyka czystego rozumu, t. 1-2, przekł. R. Ingarden, Państwowe Wydawnictwo Naukowe, Warszawa 1986.

Kierkegaard S., Bojaźń i drżenie. Choroba na śmierć, przekł. J. Iwaszkiewicz, Państwowe Wydawnictwa Naukowe, Warszawa 1982.

Längle A., Gdy rodzi się pytanie o sens: praktyczne zastosowanie logoterapii, przekł. A. Grzegorczyk, A. Szymczak, Wydawnictwo Barbelo, Warszawa 2016.

Liiceanu G., Dziennik z Păltinişu. Pajdeja jako model w kulturze humanistycznej, przekł. I. Kania, Sejny: Pogranicze, Sejny 2001.

Mazur T., Fiasko. Podręcznik nieudanej egzystencji, Wydawnictwo Carta Blanca, Warszawa 2012.

Mazur T., O stawaniu się stoikiem. Czy jesteście gotowi na sukces? Dom Wydawniczy PWN, Warszawa 2014. 
May R., O istocie człowieka. Szkice z psychologii egzystencjalnej, przekł. M. Moryń, Z. Wiese, Dom Wydawniczy Rebis, Poznań 1995.

Michalski K., Próba interpretacji: „Przedmowa” do pierwszego wydania "Krytyki czystego rozu$m u^{\prime \prime}$, Teksty: teoria literatury, krytyka, interpretacja, 1976, 3(27).

Noras A.J., Co to znaczy "być krytycznym"? [w:] Prawda a metoda, red. J. Jaskóła, A. Olejarczyk, Wydawnictwo Uniwersytetu Wrocławskiego, Wrocław 2003.

Opoczyńska M., Genealogie psychoterapii: fragmenty dyskursu egzystencjalnego, Wydawnictwo Uniwersytetu Jagiellońskiego, Kraków 2016.

Ostasz L., Psychoterapia filozoficzna. O usprawnianiu rozumu i leczeniu psychiki, Laterna, Krynica Morska 2007; Eneteia - Wydawnictwo Psychologii i Kultury, Warszawa 2011.

Peiper J., W obronie filozofii, przekł. P. Waszczenko, Instytut Wydawniczy PAX, Warszawa 1985.

Platon, Eutyfron, Obrona Sokratesa, Krition, przekł. W. Witwicki, Państwowe Wydawnictwo Naukowe, Warszawa 1958.

Platon, Teajtet, przekł. W. Witwicki, Państwowe Wydawnictwo Naukowe, Warszawa 1959.

Popielski K., Mamcarz P., Trauma egzystencjalna a wartości, Wydawnictwo Difin, Warszawa 2015.

Rosińska Z., Psychoterapia i filozofia, [w:] Psychoterapia pogranicza. Podręcznik akademicki, red. L. Grzesiuk, H. Suszek, Eneteia - Wydawnictwo Psychologii i Kultury, Warszawa 2012.

Stankiewicz P., Sztuka życia wedtug stoików, Wydawnictwo W.A.B., Warszawa 2014.

Studia Philosophiae Christianae, 2018, 54, 3.

Szulińska J., Eckharta Rushmanna "Doradztwo filozoficzne”, Przegląd Filozoficzny - Nowa Seria, 2000, 3(35).

Vernezze P.J., Don't worry, Be Stoic. Antyczna mądrość na trudne czasy, przekł. A. Aduszkiewicz, Wydawnictwo Czarna Owca, Warszawa 2013.

Višňovský E., Doradztwo filozoficzne jako forma praktyki filozoficznej, przekł. M. Aleksandrowicz, Colloquia Communia, 2001, 71.

Wahl J., Krótka historia egzystencjalizmu, przekł. J.A. Prokopski, Oficyna Wydawnicza Atut, Wrocław 2004.

Wprowadzenie do psychologii egzystencjalnej, red. M. Opoczyńska, Wydawnictwo Uniwersytetu Jagiellońskiego, Kraków 1999.

Yalom I.D., Psychoterapia egzystencjalna, przekł. A. Tanalska-Dulęba, Instytut Psychologii Zdrowia. Polskie Towarzystwo Psychologiczne, Warszawa 2008.

Znak, 2019, 1(764). 